А. М. Коломієць // Управління соціальними системами. - Харків, 2001. - № 4. С. 20-26. 2. Коломієць А. М. Можливості новітніх інформаційних технологій у підготовці педагогічних кадрів / А. М. Коломієць // Комп’ютерно-орієнтовані системи навчання: Зб. наук. пр. - К. : НПУ ім. М. П. Драгоманова. - Випуск 5. 2002. - С. 173-181. 3. Андрусич О. Комп’ютерна підтримка курсу «Сходинки до інформатики»: зроблено перший крок / О. Андрусич // Початкова школа. - 2006. № 7. - С. 41-43. 4. Босова Л. Комбинированные уроки информатики / Л. Босова // Информатика и образование. - 2000. - № 3. - С. 85-93. 5. Державний стандарт початкової загальної освіти [Електронний ресурс]. - Режим доступу: http://www.mon.gov.ua/education/average 6. Кивлюк О. Аналіз наукових досліджень 3 проблематики пропедевтики інформатики в початковій школі / О. Кивлюк// Інформатика та інформаційні технології в навчальних закладах. - 2006. - № 6. С. 69-72. 7. Снігур О. М. Засоби інформаційних технологій у системі підготовки майбутнього вчителя початкової школи: Спецкурс / О. М. Снігур. - К. : «ЗАТ HEBTEC», 2004. - 59 с. 8. Яшанов С. М. Формування у майбутніх учителів умінь і навичок самостійної навчальної роботи у процесі використання нових інформаційних технологій : автореф. дис. на здобуття наук. ступеня канд. пед. наук : спец. 13.00.09 «Теорія навчання» / С. М. Яшанов. - К., 2003. - 20 с.

\title{
ДИДАКТИЧНІ УМОВИ РОЗВИТКУ ІНФОРМАЦІЙНО-КОМУНІКАЦІЙНИХ КОМПЕТЕНТНОСТЕЙ МАГІСТРАНТІВ У ПРОЦЕСІ ВИВЧЕННЯ ПСИХОЛОГО-ПЕДАГОГІЧНИХ ДИСЦИПЛІН
}

Зеленкова Н. І., Морозова К. О.Дидактичні умови розвитку інформаційнокомунікаційних компетентностей магістрантів у процесі вивчення психологопедагогічних дисциплін

У статті проаналізовано напрацювання учених-науковців стосовно проблеми впливу на інформаційно-комунікаційні компетентності майбутніх фахівців, обгрунтовано основні дидактичні умови розвитку інформаційно-комунікаційних компетентностей магістрантів у процесі вивчення психолого-педагогічних дисциплін.

Ключові слова: інформаційно-комунікаційна компетентність, розвиток, магістрант, дидактичні умови, психолого-педагогічні дисципліни.

Зеленкова Н. И., Морозова К. О. Дидактические условия развития информационно-коммуникационных компетентностей магистрантов в процессе изучения психолого-педагогических дисциплин

В статье проанализированы наработки ученых-исследователей по проблеме воздействия на информационно-коммуникационные компетентности будущих специалистов, обоснованы основные дидактические условия развития информационно-коммуникационных компетенций магистрантов в процессе изучения психолого-педагогических дисциплин.

Ключевые слова: информационно-коммуникационная компетентность, развитие, магистрант, дидактические условия, психолого-педагогические дисциплины. 
Zelenkova N. I., Morozova K. O. Didactic terms of development of ict-competencies of undergraduates in the study of psycho-pedagogical subjects

The basic didactic terms of development of ICT competencies of undergraduates in the study of psycho-pedagogical subjects are represented in the article. Achievements of scientists and researchers regarding the problems have been analyzed by authors.

Key words: information and communication competencies, undergraduates, didactic terms, development, undergraduate, psychological and pedagogical disciplines.

Формування та розвиток інформаційно-комунікаційних компетентностей у студентів, зокрема магістрантів, що не зорієнтовані на інформаційні технології як на фах, стає невід'ємним аспектом навчально-виховного процесу у вищих навчальних закладах країни. Той факт, що єдиним спільним інваріантним складником ОПП ОКР «магістр» для всіх спеціальностей є вивчення дисциплін психолого-педагогічного циклу, надає змогу обгрунтувати загальну дидактичну модель розвитку ІК-компетентностей магістранів. Ураховуючи це, метою статті є обгрунтування специфічних дидактичних умов розвитку ІКК магістрантів у процесі вивчення таких дисциплін.

Дослідження дидактичних засад розвитку ІКК є нагальним питанням у колах вітчизняних та зарубіжних науковців (В. Биков, А. Гуржій, М. Головань, М. Жалдак, Г. Козлакова, Ю. Машбиць, Н. Морзе, В. Соловйов, Ю. Триус, С. Тришина, А. Кравцова, А. Кузнецов, Д. Матрос, Н. Роберт та ін.).

Вагомим для нашої праці $\epsilon$ визначення поняття «дидактичні умови», обгрунтоване Ю. Машбицем: це фактори, що впливають на методи i, взаємодіючи 3 методом, впливають на його відносну ефективність [7, с. 51].

Під дидактичними умовами розвитку ІК-компетентностей магістрантів у процесі вивчення психолого-педагогічних дисциплін ми розуміємо цілеспрямований відбір та організацію обставин процесу навчання, завдяки яким розвиток означених компетентностей магістрантів буде успішним.

Актуальними у контексті нашого дослідження вважаємо позиції сучасних науковців щодо окресленого питання.

У працях І. Соколовської зазначається, що основними умовами, які сприяють реалізації моделі формування ІКК компетентностей студентів є: включення їх до спеціально організованої розвивальної навчально-дослідної діяльності, яка грунтується на засвоєнні способів здобуття знань із різних джерел інформації; розвиток інформаційних потреб та умінь, ціннісного ставлення до професійнопедагогічної інформації; забезпечення суб'єктної позиції студента в процесі його творчої самореалізації й саморефлексії; введення бально-рейтингової системи оцінювання якості знань студентів тощо [7, с. 56].

Т. Грицькою обгрунтовано основні умови формування ІКК студентів технічних спеціальностей, серед яких актуальними для нашого дослідження вважаємо такі: забезпечення доступу та використання у навчально-виховному процесі сучасних апаратних засобів та інформаційних ресурсів; розроблення адаптованого методичного забезпечення навчального процесу; забезпечення зацікавленості студентів у навчанні [8, с. 58].

Звертаємо увагу на положення, обгрунтовані у дослідженнях Н. Баловсяк, де автор говорить про те, що формування IКК набуває ефективності за умов, при яких цей процес розглядається як складник професійної підготовки та грунтується на технологічній моделі, що визначає мету, функції, умови означеного процесу [7, с. 65]. 
Проаналізувавши умови формування та розвитку ІКК студентів за різними напрямами навчання, а також на основі вивчення окремих циклів дисциплін, можемо сказати, що найбільш популярними у цьому контексті $\epsilon$ залучення студентів до використання ІКТ під час самостійної навчальної діяльності, організація інформаційного навчального середовища та впровадження різних сучасних форм та методів навчання із використанням IКТ. При цьому акцентуємо увагу на вимогах до організації освітнього процесу у контексті підвищення рівня ІК-компетентностей, які висуває у своїй праці С. Астанін: забезпечення цілісного інформаційно-розвивального освітнього середовища шляхом об'єднання зусиль педагогічного, управлінського, технічного персоналу; забезпечення побудови навчальних занять на основі міждисциплінарної інтеграції задля розширеної інформаційної підготовки [1, с. 45-49].

Погоджуємося 3 висновком педагогів-дослідників про те, що основним завданням навчального процесу у вищій школі $\epsilon$ цілеспрямована та планомірна підготовка майбутніх фахівців різного профілю до творчої життєдіяльності в сучасному суспільстві. І. Кобилянський і Л. Рувінський зауважують, що навчальновиховний процес у вищій школі відзначається низкою особливостей: вивчення кожної наукової дисципліни студентами відбувається в динаміці; наявність інтеграції наукових досліджень до навчального процесу; значний обсяг самостійної навчально-пізнавальної діяльності студентів, спрямованої на опрацювання різних наукових джерел; спрямованість на ефективну професійну підготовку майбутніх фахівців [7, с. 59-65].

У контексті нашого дослідження актуальною є думка 3. Курлянд про те, що необхідність інтенсифікації навчально-виховного процесу 3 педагогіки вимагає встановлення доцільного співвідношення різних форм навчальних занять задля усунення непотрібного дублювання навчального матеріалу, подолання формалізму у викладанні педагогіки [7, с. 35-37].

Робимо висновок, що компетентнісний підхід, будучи зорієнтованим, насамперед, на нове бачення цілей та оцінку результатів навчання, висуває свої вимоги і до інших компонентів освітнього процесу, а саме до змісту, педагогічних технологій, засобів контролю та оцінки тощо. Головною вимогою реалізації компетентнісного підходу в підготовці магістрантів як майбутніх наукових кадрів стає проектування й реалізація таких технологій навчання, які створювали б ситуації залучення студентів до різнихі видів діяльності.

Пріоритетність компетентісного підходу, який передбачає інтеграцію інноваційних технологій у навчально-виховний процес, дозволяє відзначити, що одним із головних напрямків упровадження будь-яких нових технологій у навчально-виховний процес, зокрема інформаційно-комунікаційних, $\epsilon$ надання викладачеві й студентові права вільного вибору технологій навчання, форм i методів роботи. Це впливає на результативність через урізноманітнення можливостей подачі навчального матеріалу та організації навчально-виховного процесу загалом, ураховуючи особливості кожного зі студентів.

Із визначення ІК-компетентності випливає, що така якість особистості передбачає засвоєння магістрантами не окремих елементів знань та умінь, які не пов'язані один 3 одним, а оволодіння комплексною процедурою розв'язання професійних, педагогічних та завдань іншого характеру. Задля реалізації окресленого процесу необхідним є створення особливого простору для навчальнопізнавальної діяльності, де магістранти будуть залучені до колективного пошуку істини, зможуть сформувати й аргументувати власну позицію, а також толерантно 
ставитися до альтернативних думок та застосовувати власний досвід для виконання тих чи тих завдань. Щоб надати студентам максимально комфортні умови для навчання в такому форматі доцільно застосовувати інноваційні технології навчання (ІКТ, особистісно-зорієнтовані, проектні, мультимедійні тощо). Навчальновиховний процес, який грунтується на сучасних інформаційно-комунікаційних технологіях, створює передумови для розвитку принципово нової культури організації навчання.

Відтак, першою дидактичною умовою розвитку інформаційно-комунікаційних компетентностей магістрантів у процесі вивчення психолого-педагогічних дисциплін постає використання інноваційних, особистіснозорієнтованих технологій навчання.

У контексті компетентнісних тенденцій у сучасній педагогічній практиці дослідниками інтенсивно розробляються методичні комплекси та посібники. У навчально-виховний процес вищої школи впроваджуються елементи інноваційних педагогічних технологій, відбувається зміщення акценту на досвід та діяльність особистості. Ураховуючи інформатизацію суспільства, найпоширенішими технологіями навчання нині $є$ інформаційно-комунікаційні.

Звертаємо увагу на центральну роль досвіду та самостійної діяльності студентів в умовах компетентнісного підходу, це диктує свої вимоги щодо організації процесу навчання. Сучасні нормативні документи Міністерства освіти i науки України визначають самостійну діяльність провідним видом навчальнопізнавальної діяльності студентів, зокрема магістрантів. Навчальний час, відведений на самостійне опрацювання матеріалу, регламентується навчальним планом у межах від $30 \%$ до $60 \%$ від загального обсягу навчального часу, відведеного на вивчення дисципліни [4]. У робочих навчальних програмах передбачено завдання для самостійної роботи магістрантів у міжсесійний період, завдання практичного характеру, теоретичні питання для самоконтролю, а також для підготовки до складання іспиту (заліку) з дисципліни.

3 огляду на те, що магістрантів готують до розв'язання специфічних професійних завдань, зокрема й інноваційного, педагогічного характеру, особливістю їх самостійної навчальної діяльності визначаємо спрямованість на результативність роботи, усвідомлення та систематизацію навчального матеріалу, набуття певного досвіду. Специфіка дослідження - розвиток ІКК магістрантів зумовлює нагальну потребу застосування студентами під час самостійної роботи відповідних засобів та елементів ІКТ. Практична частина нашого дослідження грунтується на дисциплінах психолого-педагогічного циклу, що породжує необхідність опосередкованого впливу на інформаційно-комунікаційні компетентності студентів у процесі навчання. На підгрунті вищезазначеного виокремлюємо другу дидактичну умову розвитку ІКК магістрантів у процесі вивчення психолого-педагогічних дисциплін: наявність відповідної технологічної та методичної навчальної бази, зокрема авторських методичних рекомендацій щодо застосування IКT у процесі вивчення конкретної дисципліни. Названа умова передбачає створення необхідних та зрозумілих студентам, що не зорієнтовані на інформаційні технології як на фах, методичних комплексів та вказівок щодо застосування таких технологій у процесі вивчення психолого-педагогічних дисциплін задля покращення сприйняття навчального матеріалу та розвитку в них відповідних компетентностей.

У контексті одного із основних завдань Болонського процесу - створення міжнародного глобального освітнього середовища, головною перевагою якого $є$ 
подання навчального матеріалу в дидактично уніфікованому й формалізованому вигляді та створення умов використання його контенту в будь-якому місці та в будь-який час [5], - акцентуємо увагу на необхідності поступової його реалізації та залучення студентів до місцевих електронних ресурсів з дисципліни, вироблення у них поняття та усвідомлення можливостей і переваг такого варіанту подання i збереження інформації, а також оптимізації їх навчальної діяльності (аудиторної та самостійної).

Ураховуючи специфіку самостійної навчальної діяльності магістрантів, уважаємо, що самостійність у здобутті знань передбачає уміння визначати мету та завдання діяльності, організовувати пошук інформації, знаходити відповіді в різноманітних джерелах, систематизувати їх та створювати власні варіанти розв'язання завдань. Відповідно до основної мети дослідження (розвиток ІКК магістрантів), навчальний матеріал має бути поєднаний 3 елементами IКТ та організований за їх допомогою.

Проблематичним нині $\epsilon$ поєднання необхідної навчальної інформації із залученням IKT у певному комплексі, адже в більшості випадків електронні підручники (посібники, рекомендації тощо) зберігаються на окремих електронних носіях у різних форматах, що утруднює пошук та систематизацію необхідної інформації студентами, деструктивно впливає на якість ІК-компетентностей, а не розвиває їх. Тому необхідним $є$ приведення усієї навчальної інформації 3 дисципліни до спільного електронного ресурсу - web-сторінки (сайту, у подальшому - порталу).

Використання нових інформаційних технологій дає змогу створити на занятті комфортне середовище, допомагає активізувати творчий потенціал студентів, сприяє розвитку критичного мислення та формує відповідні професійні навички. При цьому змінюється парадигма навчання: більше уваги приділяється виробленню умінь самостійно здобувати знання в умовах дослідницької діяльності. Застосування IKT у навчанні посилює міжпредметні зв'язки, що сприяє забезпеченню співвідношень між державними стандартами освіти. Комп'ютернозорієнтовані освітні дидактичні системи та комплекси розвивають у студентів потребу у розширенні та поглибленні своїх знань, умінні зважено приймати рішення та відповідати за їх наслідки, що є невід'ємним складником виховання гармонійно розвиненої особистості, а також чинником розвитку інформаційнокомунікаційних компетентностей студентів, акцентуючи при цьому увагу не на IКТ як предметі діяльності, а саме на навчальному матеріалі $з$ дисциплін.

Отже, третьою дидактичною умовою розвитку ІКК магістрантів у процесі вивчення психолого-педагогічних дисциплін визначаємо створення методично організованого електронного ресурсу з дисципліни. Означена дидактична умова $\epsilon$ тим чинником, який покращить самостійну навчальну роботу магістрантів, сформує у них відповідні навички роботи 3 електронними ресурсами, дозволить зберігати необхідний обсяг навчальної інформації в комплексі на одному сайті, не перенавантажуючи таким чином студентів зайвими інтернет-сервісами.

Вплив на розвиток ІКК магістрантів має бути систематичним та враховувати особливості їх навчальної діяльності. Навчальний матеріал із психологопедагогічних дисциплін досить різноплановий та творчий, тому у процесі навчання студенти мають виявляти уміння мислити, робити висновки, розв'язувати проблемні завдання та пропонувати власні підходи до проблематики. У поєднанні 3 ІКТ-технологіями цей процес може стати мінливим, оскільки означений цикл не можна повністю інформатизувати, доцільним $є$ включення лише окремих елементів 
IКТ у методи, форми навчання, а також інтеграція ІКТ -засобів. Отримання позитивного кінцевого результату в навчально-виховному процесі передбачає періодичний контроль на певних етапах, розвиток компетентностей також має підлягати систематичному контролю із визначенням вимог до сформованості компетентностей та подальших стратегій впливу на них. Це зумовлює необхідність систематичного відстеження динаміки розвитку ІК-компетентностей магістрантів, можливість проведення окресленого аналізу надає такий тип оцінки процесів, як моніторинг. Він виконує кілька основних функцій, які дозволять за необхідності скорегувати програму розвитку ІКК, замінити засоби, вдосконалити форми та методи навчання, відстежити базові тенденції: фіксація результатів навчання, діагностична виявлення наявного рівня сформованості ІКК, акцент на основних поняттях тематичного блоку, визначення основних характеристик якості підготовки студентів [3, с. 45].

Четвертою дидактичною умовою розвитку ІКК магістрантів у процесі вивчення психолого-педагогічних дисциплін $\epsilon$ розроблення програми моніторингу рівнів сформованості інформаційно-комунікаційних компетентностей, яка дозволить збирати необхідні дані фактично безперервно, що сприятиме виявленню особливостей цього процесу, обгрунтуванню нових стратегій та способів розвитку означених компетентностей у процесі вивчення психолого-педагогічних дисциплін.

Усі визначені дидактичні умови детермінують усвідомлення необхідності створення комплексної дидактичної моделі, обгрунтування та розроблення якої передбачає врахування особливостей розвитку інформаційно-комунікаційних компетентностей магістрантів у процесі вивчення психолого-педагогічних дисциплін.

\section{Література}

1. Астанин С. В. Компьютерные образовательные технологии: [учеб. пособ.] / С. В. Астанин. - Таганрог : ИЦ Таганрог. гос. пед. ин-та, 2009. - 192 с. 2. Байраківський А. І. Особливості самостійної роботи студентів в умовах запровадження комп'ютерних технологій у навчальному процесі / А. I. Байраківський, Н. І. Бойко // Болонський процес: трансформація навчального процесу у технології навчання: матеріали III міжнародної науково-методичної конференції ДУІКТ. - К., 2006. - С. 247-251. З. Головань М. С. Розвиток пізнавальної активності учнів в процесі навчання алгебри і початків аналізу на основі НІТ: дис. ... канд. пед. наук: 13.00.02 / Український державний педагогічний ун-т ім. М. П. Драгоманова. - К., 1997. - 177 с. 4. Міністерство освіти та науки України. Про впровадження кредитно-модульної системи організації навчального процесу [Електронний ресурс]: Наказ від 30.12.2005 № 774. - Режим доступу: http://uazakon.com/ document/fpart30/idx30417.htm. 5. Інформаційні матеріали: Болонський процес [Електронний ресурс].- Режим доступу: http://www. mon.gov.ua/main.php?query=education/ higher/bolpr. 6. Гуріна Т. М. Формування інформаційної компетентності в процесі фахової підготовки вчителя іноземної мови [Електронний ресурс] / Т. М. Гуріна. - Режим доступу: http://ito.edu.ru/2003/II/3/II-33305.html 7. Компетентнісний підхід у сучасній освіті: світовий досвід та українські перспективи: Бібліотека $з$ освітньої політики / за заг. ред. О. В. Овчарук. - К. : «К.І.С.», 2004. - 112 с. 8. Педагогіка вищої школи: [навч. посіб.] / 3. Н. Курлянд, Р. І. Хмелюк, А. В. Семенова та ін.; за ред. 3. Н. Курлянд. - К. : Знання, 2005. 399 с. 9. Туркот Т. І. Педагогіка вищої школи: [навч. посіб. для вузів] / Т. І. Туркот - К. : Кондор, 2011. -628 с. 